\title{
Evaluation of "Pampa-Corte" simulation model in different beef cattle fattening systems in Spain
}

\author{
Desempenho do modelo "Pampa-Corte" em diferentes sistemas de \\ terminação de bovinos na Espanha
}

\author{
Vicente Celestino Pires Silveira ${ }^{\mathrm{I}}$ Isabel Casasús ${ }^{\mathrm{II}}$ Mireia Blanco ${ }^{\mathrm{II}}$ Margalida Joy ${ }^{\mathrm{II}}$ Alberto Bernués ${ }^{\mathrm{II}}$
}

\section{- NOTE -}

\begin{abstract}
The Pampa-Corte model was developed to simulate the growth of beef cattle in grazing systems in a dynamic and mechanistic way. It was validated under Brazilian conditions. This paper aims to verify the performance of the model in conventional and alternative beef cattle finishing systems in Spain. An experimental dataset of 21 Parda de Montaña calves of similar age and weight at weaning was used to evaluate the model. They were slaughtered individually on reaching $450 \mathrm{~kg}$ liveweight. The model considered genetic group maturity rather than breed, in order to adjust growth parameters, once Parda de Montaña breed is not contemplated by AFRC (1993). Parameters from late maturing group were initially used considering adult animal size of Parda de Montaña animals; however, the best fit was with values from the early maturing group. The model predicted accurately animal growth in grazing and conventional finishing systems in Spain, although estimates were less precise when changes in animal management involved physiologic modifications.
\end{abstract}

Key words: beef cattle, growth model, maturity parameters, finishing systems

\section{RESUMO}

O modelo Pampa Corte foi desenvolvido para simular de forma dinâmica e mecanistica o crescimento de bovinos de corte em sistemas de pastejo, sendo validado nas condições de produção brasileiras. Este trabalho tem como finalidade demonstrar a performance do modelo em situações de engorda tradicionais e alternativos de bovinos de corte na Espanha. Com essa finalidade, foram utilizados dados de 21 animais inteiros da raça Parda de Montanha com similar idade e peso de desmame e que foram abatidos individualmente quando atingiram o peso vivo de $450 \mathrm{~kg}$. O modelo considera grupos genéticos no ajuste de seus parâmetros conforme AFRC (1993), entretanto, a raça Parda de Montanha não é contemplada em suas tabelas. Devido ao seu tamanho adulto, inicialmente, foram considerados os parâmetros referentes ao grupo tardio de maturidade, entretanto, os melhores ajustes ocorreram ao serem utilizados os parâmetros de animais de maturidade precoce. O modelo prediz satisfatoriamente o crescimento e terminação dos animais nos sistemas convencionais e alternativos de produção. No entanto, essas predições são menos precisas quando envolve a troca de sistema de pastoreio para confinamento total.

Palavras-chave: bovinos de corte, modelo de crescimento, parâmetros de maturidade, sistemas de terminação.

Simulation models are useful tools to reduce time and costs, in comparison to classical empiric experimentation. They are also able to address dynamic complexity and study long-term effects, allowing the researcher to control environmental and experimental conditions. Historical evolution of models used in animal nutrition was reviewed by DUMAS et al. (2008); these authors explain that pioneers in animal nutrition had to rely on mathematics in their attempt to estimate animal requirements of feedstuffs to achieve various production goals.

The Pampa Corte model was developed with the objective of simulating beef cattle growth in a dynamic and mechanistic way. Individual animal behaviour is generated through two sub-models: the

'Departamento de Educação Agrícola e Extensão Rural, Universidade Federal de Santa Maria (UFSM), Prédio 44, 97105-900, Santa Maria, RS, Brasil. E-mail: vicentesilveira@smail.ufsm.br. Autor para correspondência.

"Centro de Investigación y Tecnología Agroalimentaria de Aragón, Zaragoza, Espanhal. 
first one simulates food consumption and digestion and generates daily metabolic energy and protein production; the second sub-model considers these production rates and simulates animal live weight changes (SILVEIRA, 2002). The model was validated with experimental data (SILVEIRA \& VARGAS, 2003) and data available in literature (TREVISAN et al., 2009) with satisfactory results in Brazil. The object of this study is to verify the predictive behaviour of the Pampa Corte model indoor (concentrate and straw on ad libitum basis) and outdoor (grazing plus concentrate) fattening systems in Spain.

Experimental data from BLANCO et al. (2005) was used. Twenty-one Parda de Montaña calves, with the same age and weight at weaning, were individually slaughtered in different dates once they reached $450 \mathrm{~kg}$ liveweight. The breed is explored for meat production, mainly in medium-sized groups with extensive mountain grazing productive systems, playing an important socioeconomic role in Aragón, Cantabria and Castilla y León counties. The animals were randomly separated into three groups and weighed weekly: one group was fed concentrates and straw on ad libitum basis until slaughter $(\mathrm{CON})$, another group rotationally grazed in lucerne paddocks supplemented daily with $1.8 \mathrm{~kg}$ DM of barley until slaughter (LUC), and the third group had the same management as LUC calves for 3 months and were finished indoor, on concentrates and straw on ad libitum basis, until they reached the slaughter weight $(\mathrm{LUC}+\mathrm{CON})$. The data necessary to run the model are initial, intermediate and final weight from a specific genetic group of animals. In relation to feeding, the contents and degradability, considering a 5\% per hour passage rate, of the neutral detergent fibre (NDF) and the crude protein $(\mathrm{CP})$ for all feeds are necessary. For grazing animals is necessary to delimit the starting date and the period of utilization of pasture. The values of degradability of the $\mathrm{CP}$ of the feed were obtained from the AFRC (1993). The values 0.092 and 0.110 for the NDF degradation of the lucerne were considered according to its maturity stage (PUEYO, 1999). Values of 0.086 for concentrate and 0.026 for barley hay were obtained through the gas production technique (MAURÍCIO et al., 1999).

The Pampa Corte model considers genetic group maturity and sex to adjust growth parameters (AFRC, 1993). Since the Parda de Montaña breed is not considered by AFRC (1993), the parameters of the genetic group which in theory was the most similar to this breed was "late development", taking into account adult Parda de Montaña body size. However, the best fit was obtained when they were considered as an "early development" genetic group (Figure 1). Two factors can be related to this: first, the model was based on the equations of the AFRC (1993) originated from studies that were carried out 50 years ago (ARC, 1980), when the genetic characteristics of the animals were very different from nowadays; second, the weight at weaning that has been used traditionally as main criteria for selection programs (PEREIRA et al., 2006; ALTARRIBA et al., 2005; PHOCAS \& LALOË, 2004) could have resulted in the selection of early maturing animals.

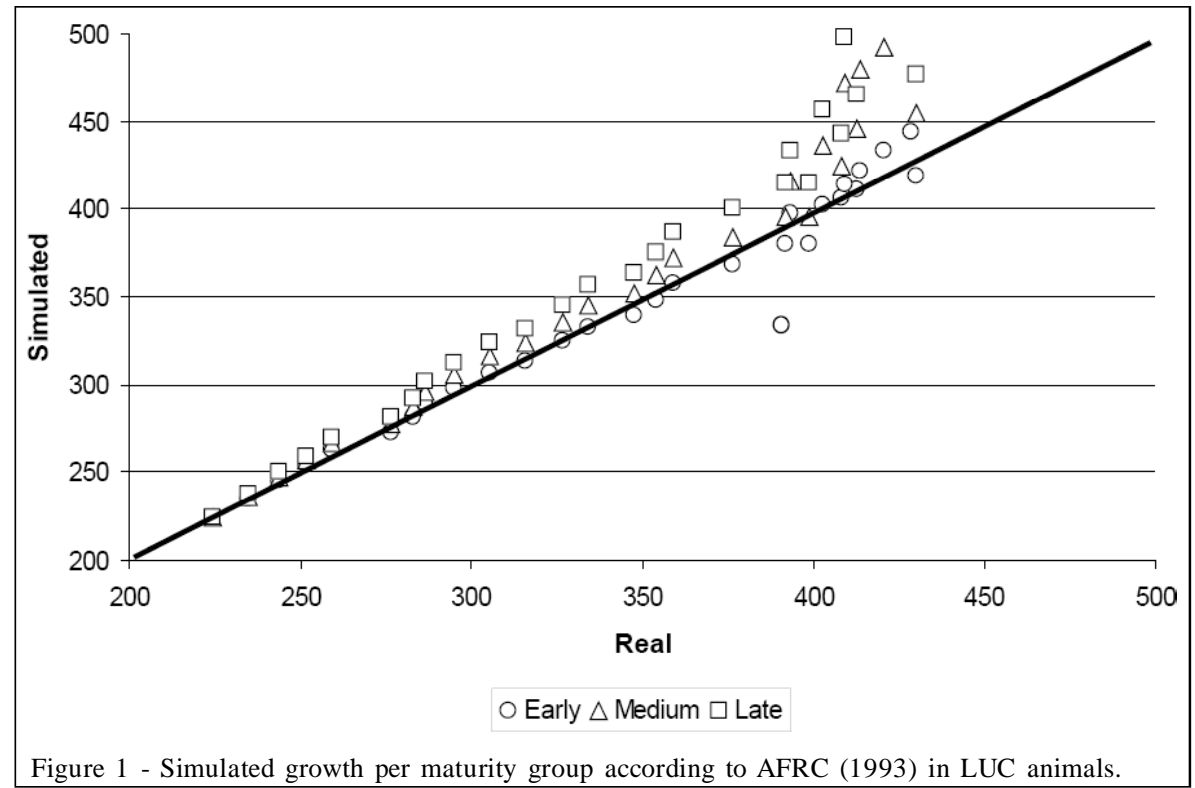

Ciência Rural, v.41, n.3, mar, 2011. 


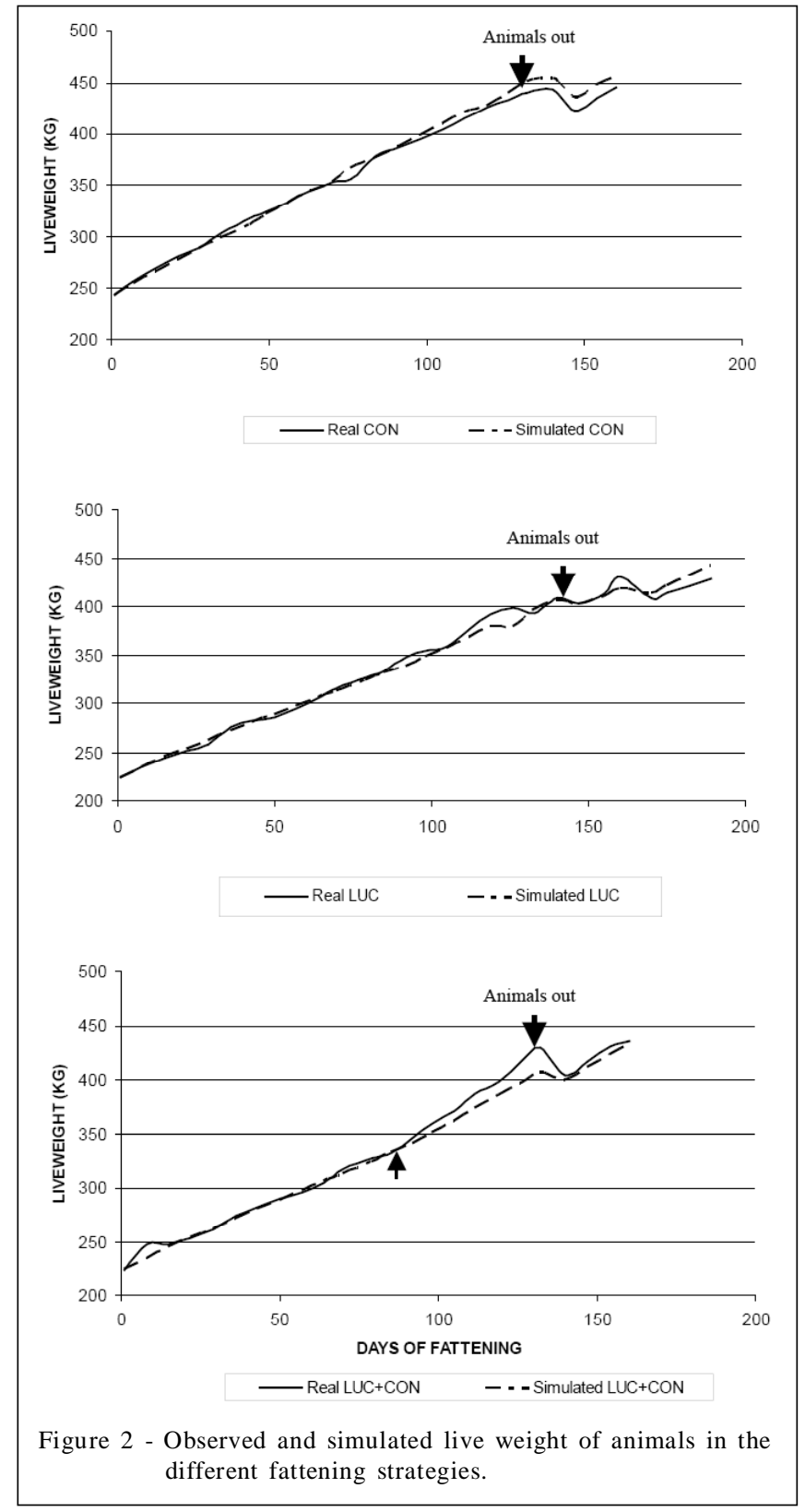

The relation between observed and simulated average liveweight per group is shown in figure 2. The model predicted accurately weight of LUC and $\mathrm{CON}$ calves but it underestimated weight gains of LUC+CON calves during the finishing period on concentrates. This can be due to the fact that the model could not simulate adequately the compensatory gain observed in this phase (BLANCO et al., 2005). On the other hand, the model kept good prediction accuracy, even when first animals reaching slaughter liveweight were eliminated from the groups.
We can conclude that the model predicts accurately animal liveweight gain from grazing and conventional finishing systems in Spain, although the estimates are less precise when changes in animal management involve physiologic modifications.

\section{ACKNOWLEDGEMENTS}

Universidade Federal de Santa Maria (UFSM), Coordenação de Aperfeiçoamento de Pessoal de Nível Superior (CAPES) and the Centro de Investigación en Tecnología Agroalimentaria de Aragón (CITA) to allow my Postdoctoral training and to become possible the elaboration of this paper. 


\section{REFERENCES}

ALTARRIBA J. et al. Consequences of selection for growth on carcass and meat quality in Pirenaica cattle. Livestock Production Science, v.95. p.103-114, 2005.

AFRC. Energy and protein requirements of ruminants. Wallingford: CAB International. 1993. 159p.

ARC. The nutrient requirements of ruminant livestock. Slough, UK: Commonwealth Agricultural Bureaux. 1980. 351p.

BLANCO, M. et al. Cebo de terneros en praderas de alfalfa:efecto de distintas alternativas de manejo sobre los rendimientos. Revista ITEA, v.26, n.I, p. 216-218, 2005.

DUMAS, A. et al. Mathematical modelling in animal nutrition: a centenary review. Journal of Agricultural Science, v.146, n.2, p.123-142, 2008. Available from: < h t t p://journals. cambridge.org/a ction / displayAbstract?fromPage $=$ online $\&$ aid $=1816684 \&$ fulltext $T y p e=$ RA\&fileId=S0021859608007703ER $>$. Access: 15 November 2008. doi: $10.1017 /$ S0021859608007703.

MAURÍCIO, R.M. et al. A semi-automated in vitro gas production technique for ruminants feedstuff evaluation. Animal Feed Science and Technology, v.79, p.321-330, 1999. ).

PEREIRA, M.C. et al. Estimativas de parâmetros genéticos de características de crescimento em um rebanho Caracu selecionado para peso ao sobreano. Revista Brasileira de Zootecnia, v.35, n.4, p.1669-1676, 2006. Available from: <http:// www.scielo.br/scielo.php? script $=$ sci_arttext\&pid $=$ S1516- 35982006000600013\&lng=es\&nrm=iso>. Access: 05 Apr. 2009. doi: 10.1590/S1516-35982006000600013.

PHOCAS F.; LALOË D. Genetic parameters for birth and weaning traits in French specialized beef cattle breeds. Livestock Production Science, v.89. p.121-128, 2004. Available from: <http://www.sciencedirect.com/science/article/B6T9B4C709P1-1/2/9fe8411c029ea7157c5b13214c02089c)>. Access: 05 Apr. 2009. doi: 10.1016/j.livprodsci.2004.02.007.

PUEYO, J. Estudio del valor nutritivo de la alfalfa en función del proceso de conservación: henificación y deshidratación. 1999. 103f. Trabajo de fin de Carrera, UNIZAR, Zaragoza, Spain.

SILVEIRA, V.C.P. Pampa Corte - um modelo de simulação para o crescimento e engorda de gado de corte. Ciência Rural, v.32, n.3, p.543-552, 2002. Available from: <http://www.scielo.br/ scielo.php? script $=$ sci_arttext \& pid = S $0103-$ $84782002000300029 \& \operatorname{lng}=$ es\&nrm=iso>. Access: 15 Nov. 2008. ISSN 0103-8478. doi: 10.1590/S0103-84782002000300029.

SILVEIRA, V.C.P.; VARGAS, A.F. da C. Performance do modelo Pampa Corte na simulação do ganho de peso de touros. In: CONGRESSO BRASILEIRO DE MEDICINA VETERINARIA, 30., 2003, Manaus. Anais... Manaus: CONVET, 2003. (CDROM).

TREVISAN, N. de B. et al. Desempenho de bovinos simulado pelo modelo Pampa Corte e obtido por experimentação. Ciência Rural, v.39, n.1, p.173-181, 2009. Available from: <http:// www.scielo.br/scielo.php? script $=$ sci_arttext\&pid=S01 03 84782009000100027\&lng=es\&nrm=iso>. Access: 05 Apr. 2009. ISSN 0103-8478. doi: 10.1590/S0103-84782009000100027. 